International Journal of Engineering \& Technology, $9(4)(2020) 871-880$
International Journal of Engineering \& Technology
SPC
Website: www.sciencepubco.com/index.php/IJET
Research paper

\title{
Comparison of seismic provisions of Andean countries
}

\author{
Adriana Mattos-Rodriguez ${ }^{1 *}$, Stevens Barraza ${ }^{2}$, Camilo Verbel Almario ${ }^{2}$ \\ ${ }^{I}$ Professor in Civil Engineering at Universidad de la Costa, Barranquilla, Colombia \\ ${ }^{2}$ Student of the Civil Engineering Program at Universidad de la Costa, Barranquilla, Colombia \\ *Corresponding author E-mail: amattos@cuc.edu.co
}

\begin{abstract}
This paper presents a seismic provisions comparison used in the countries of the Andean region. A brief summary of the Andean region seismicity, showing historical seismicity and the probability of earthquake occurrence in each Andean country and the overall zone is pre-sented; then a seismic provisions comparison is presented in tables taking into account the seismic hazard according to the peak ground acceleration, the site effects according to the soil classification and response spectra pseudo-acceleration. Finally, a static analysis of seismic force is carried out for each country in an intermediate-to-high seismic zone, the base design shear force is computed, and the results are compared.
\end{abstract}

Keywords: Seismic Provisions; Historical Seismicity; Shear Base Force; Andean Region; Building Code.

\section{Introduction}

The development of the sustainable development goals in the 2030 Agenda[1] and the creation of the Sendai Framework for Disaster Risk Reduction[2] have made investment a priority in order to achieve more resilient cities. Paraphrasing what is stipulated in the SDG 11[1], these objectives are focused in achieving a considerable reduction in the number of deaths and in the number of people affected, substantially decreasing direct economic losses relative to global gross domestic product caused by disasters, while substantially increasing the number of cities and human settlements adopting and implementing integrated policies and plans towards resilience to disasters. Additionally, developing and implementing, in line with the Framework, holistic disaster risk management at all levels[2].

Building codes are created to regulate construction starting from the structural conception, providing minimum values for building safety. Each country has different characteristics in terms of seismic hazard, construction practices, construction materials, skilled manpower and even ease of obtaining resources for construction, which could determine seismic risk or safety in a determined zone.

The creation, updating and permanent implementation of building codes and the incorporation of risk in land-use planning is in accordance with some of the SDGs established in the 2030 Agenda and the Sendai Framework for Disaster Risk Reduction. The adoption of appropriate seismic provisions in building codes promotes resilience, seeking to prevent the collapse of buildings in the face of major seismic events and preserving human life.

\section{Background}

Comparisons of building codes in active seismic zones, especially of seismic provisions, have been made by many authors recently. Those carried out previously by Chavez[3] in Latin America, by Giri [4] in Nepal, India, Japan and EU; and by Santos [5] who took into account codes in different continents, have had the purpose of assessing the seismic vulnerability; or by Khose [6] who makes a comparison in the design base shear in selected seismic codes. Those authors have different objectives, such as, verifying discrepancies between codes, assisting to the future improvement of the various seismic standards, and contributing in the process of harmonization of different codes of the world respectively.

This is an important exercise to execute regularly because codes vary along time, in order to provide quality of information, as mentioned by Santos, to assist code creation or updating seismic provisions.

\section{Andean region seismicity}

The mountain system of the Andes crosses the South American countries of Venezuela, Colombia, Peru, Ecuador and Bolivia, and also establishes the geographical boundary between Chile and Argentina. Its origin comes from a subduction process of the Nazca plate with the South American plate, in most of its length. The Antarctic, Cocos and the Caribbean plates also influence its formation (Figure 1a[7]). The permanent interaction of the Nazca and South American plates through subduction causes most of the seismic events which occur in the Andean countries [8]. The distance from the trench to the coast of South America, the difference in congruence of the plates and the 
presence of active faults increase and diversify the seismicity in the Andean region, among which is the inter-plate, that also makes countries in the southernmost part of the continent prone to tsunamis. Large seismic events have occurred in the recent decade, in several countries of the Andean region, consistent with the probability of occurrence of events of considerable magnitude in the area (Figure 1b), as were Bio Bio - Chile Mw 8.8 (2010), Iquique - Chile Mw 8.2 (2014), Illapel - Chile Mw 8.3 (Tsunamigenic, 2015), Muisne - Ecuador Mw 7.8

(A)

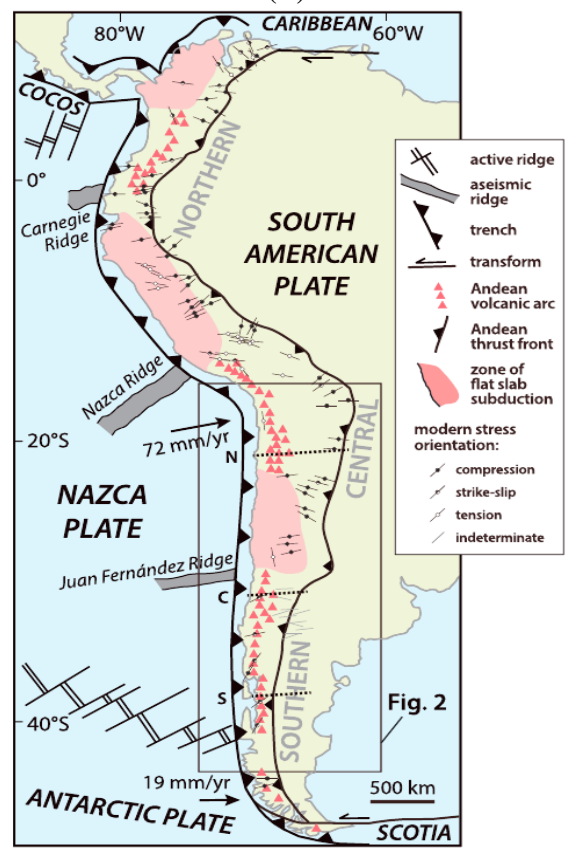

(B)

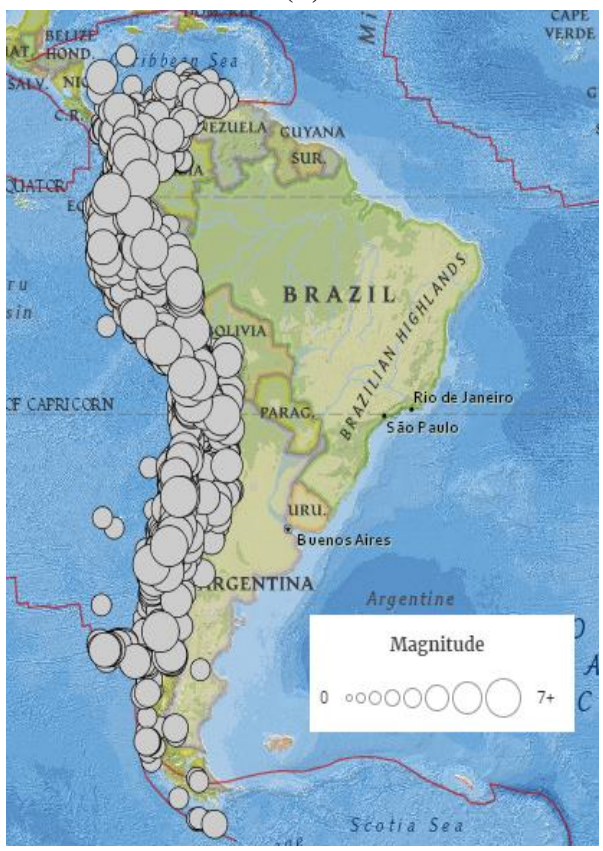

Fig. 1: A) Map of Western South America (Horton [7]) ; B) Earthquakes M >4,5 2000- 2020. Source: Retrieved from: Https://Earthquake.Usgs.Gov/Earthquakes/Map.

\subsection{Historical seismicity}

Each country of the Andean has had large seismic events, but not all countries have the same capacity to measure all earthquakes. Even small events are not measured because the seismic monitoring network is limited only to the zones where more seismic activity is presented and, in some cases, old seismic data could be mishandled or mismanaged. Tables 1 to 7 present the data collected in the USGS catalogue (https://earthquake.usgs.gov/earthquakes/search/), with the data analysis interval varying for the larger magnitudes, to achieve completeness for each country. Figures 2 to 8 show the Gutenberg-Richter relationship, and occurrence probability according to Poisson probability distribution model for each country in an interval up to 100 years.

Table 1: Data Collected for Argentina in USGS Catalog to Generate Figure 2

\begin{tabular}{lllll}
\hline Magnitude & Number of Seismic Events & Final Year & Initial Year & Interval (Years) \\
\hline $4.5-4.9$ & 1038 & 2020 & 2000 & 20 \\
$5-5.4$ & 173 & 2020 & 2000 & 2000 \\
$5.5-5.9$ & 63 & 2020 & 2000 & 20 \\
$6-6.4$ & 25 & 2020 & 1919 & 19 \\
$6.5-6.9$ & 19 & 2020 & 1919 & 101 \\
$7-7.4$ & 14 & 2020 & 101 \\
\hline
\end{tabular}

Table 2: Data Collected for Bolivia in USGS Catalog to Generate Figure 3

\begin{tabular}{|c|c|c|c|c|}
\hline Magnitude & Number of Seismic Events & Final Year & Initial Year & Interval (Years) \\
\hline $4.5-4.9$ & 254 & 2020 & 2000 & 20 \\
\hline $5-5.4$ & 62 & 2020 & 2000 & 20 \\
\hline $5.5-5.9$ & 11 & 2020 & 2000 & 20 \\
\hline $6-6.4$ & 8 & 2020 & 2000 & 20 \\
\hline $6.5-6.9$ & 9 & 2020 & 1928 & 92 \\
\hline $7-7.4$ & 1 & 2020 & 1928 & 92 \\
\hline $7.5-7.9$ & 1 & 2020 & 1928 & 92 \\
\hline $8-8.4$ & 1 & 2020 & 1928 & 92 \\
\hline
\end{tabular}

Table 3: Data Collected for Chile in USGS Catalog to Generate Figure 4

\begin{tabular}{lllll}
\hline Magnitude & Number of Seismic Events & Final Year & Initial Year \\
\hline $4.5-4.9$ & 2981 & 2020 & 2000 & 2000 \\
$5-5.4$ & 867 & 2020 & 1906 & 20 \\
$5.5-5.9$ & 594 & 2020 & 1906 & 114 \\
$6-6.4$ & 254 & 2020 & 2020 & 1906 \\
$6.5-6.9$ & 103 & 2020 & 1906 & 114 \\
$7-7.4$ & 17 & 2020 & 1906 & 114 \\
$7.5-7.9$ & 8 & 2020 & 1906 & 114 \\
$8-8.4$ & 2 & 2020 & 1906 & 114 \\
$8.5-8.9$ & 1 & 2020 & 1906 \\
$9.5-9.9$ & & & & \\
\hline
\end{tabular}


Table 4: Data Collected for Colombia in USGS Catalog to Generate Figure 5

\begin{tabular}{lllll}
\hline Magnitude & Number of Seismic Events & Final Year & Initial Year \\
\hline $4.5-4.9$ & 431 & 2020 & 2000 & 2000 \\
$5-5.4$ & 79 & 2020 & 1924 & 20 \\
$5.5-5.9$ & 375 & 2020 & 1924 & 96 \\
$6-6.4$ & 28 & 2020 & 96 & 924 \\
$6.5-6.9$ & 15 & 2020 & 2020 & 1924 \\
$7-7.4$ & 7 & 2020 & 96 & 1924 \\
$8-8.4$ & 1 & & 96 & 96 \\
\hline
\end{tabular}

Table 5: Data Collected for Ecuador in USGS Catalog to Generate Figure 6

\begin{tabular}{|c|c|c|c|c|}
\hline Magnitude & Number of Seismic Events & Final Year & Initial Year & Interval (Years) \\
\hline $4.5-4.9$ & 314 & 2020 & 2000 & 20 \\
\hline $5-5.4$ & 89 & 2020 & 2000 & 20 \\
\hline $5.5-5.9$ & 63 & 2020 & 1906 & 114 \\
\hline $6.5-6.9$ & 19 & 2020 & 1906 & 114 \\
\hline $7-7.4$ & 9 & 2020 & 1906 & 114 \\
\hline $7.5-7.9$ & 4 & 2020 & 1906 & 114 \\
\hline $8.5-8.9$ & 1 & 2020 & 1906 & 114 \\
\hline
\end{tabular}

Table 6: Data Collected for Peru in USGS Catalog to Generate Figure 7

\begin{tabular}{|c|c|c|c|c|}
\hline Magnitude & Number of Seismic Events & Final Year & Initial Year & Interval (Years) \\
\hline $4.5-4.9$ & 1203 & 2020 & 2000 & 20 \\
\hline $5-5.4$ & 305 & 2020 & 2000 & 20 \\
\hline $5.5-5.9$ & 71 & 2020 & 2000 & 20 \\
\hline $6.5-6.9$ & 41 & 2020 & 1906 & 114 \\
\hline $7-7.4$ & 23 & 2020 & 1906 & 114 \\
\hline $7.5-7.9$ & 15 & 2020 & 1906 & 114 \\
\hline $8-8.4$ & 6 & 2020 & 1906 & 114 \\
\hline
\end{tabular}

Table 7: Data Collected for Venezuela in USGS Catalog to Generate Figure 8

\begin{tabular}{|c|c|c|c|c|}
\hline Magnitude & Number of Seismic Events & Final Year & Initial Year & Interval (Years) \\
\hline $4.5-4.9$ & 152 & 2020 & 2000 & 20 \\
\hline $5-5.4$ & 31 & 2020 & 2000 & 20 \\
\hline $5.5-5.9$ & 4 & 2020 & 2000 & 20 \\
\hline $6-6.4$ & 3 & 2020 & 2000 & 20 \\
\hline $6.5-6.9$ & 4 & 2020 & 1900 & 120 \\
\hline $7-7.4$ & 2 & 2020 & 1900 & 120 \\
\hline $7.5-7.9$ & 1 & 2020 & 1900 & 120 \\
\hline
\end{tabular}

(A)

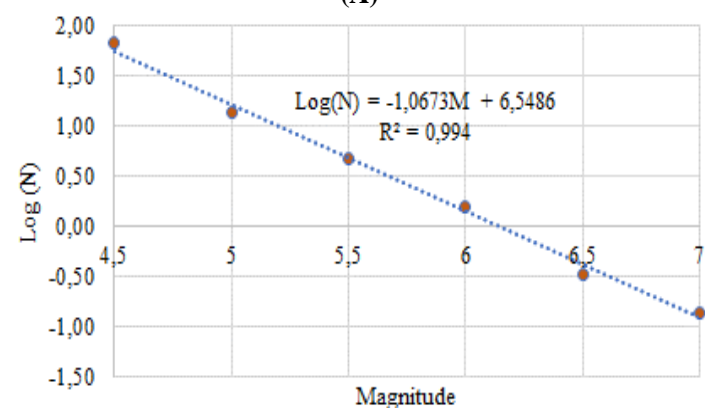

(B)

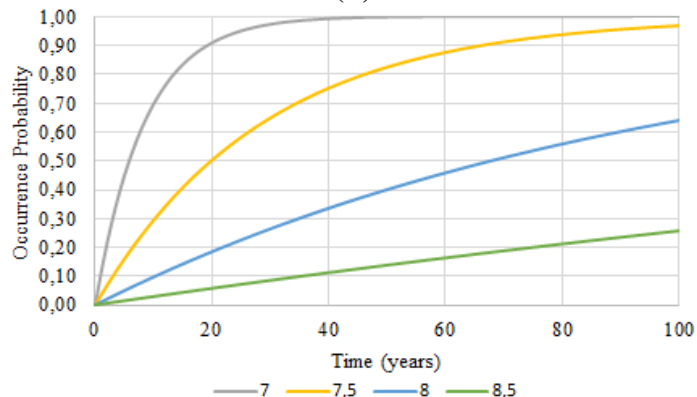

Fig. 2: A) Guttenberg-Richter Argentina $M>4,5(M \leq 6,5$ (2000-2020), $M>6,5$ (1919-2020)) B) Probability of Earthquake Occurrence in Argentina.

(A)

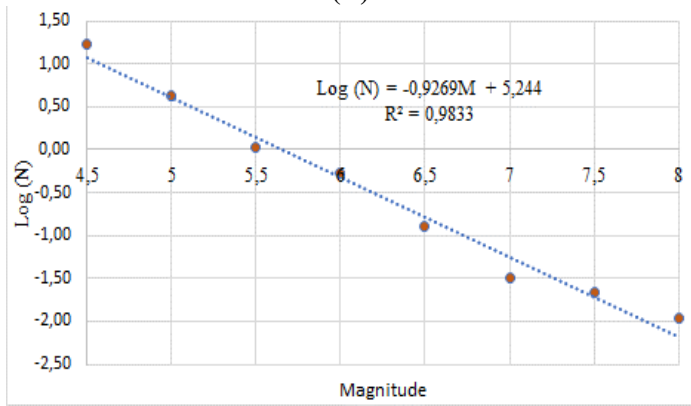

(B)

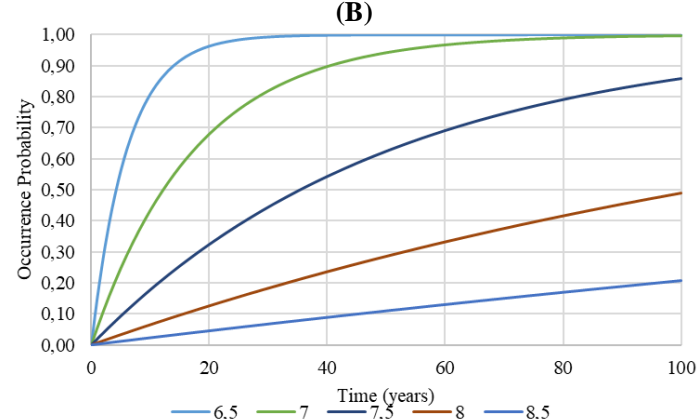

Fig. 3: A) Guttenberg-Richter Bolivia $M>4,5(M \leq 6,5$ (2000-2020), $M>6,5$ (1928-2020)). B) Probability of Earthquake Occurrence in Bolivia. 
(A)

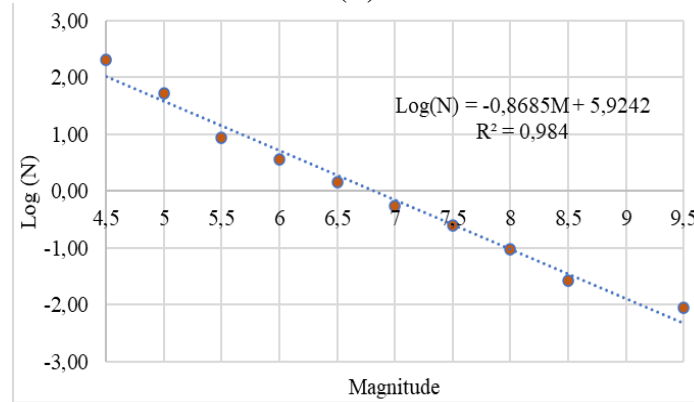

(B)

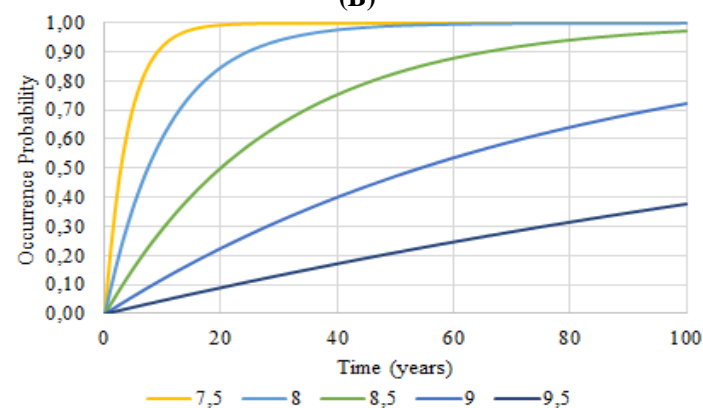

Fig. 4: A) Guttenberg-Richter Chile M>4,5 (M $\leq 5,5$ (2000-2020), $M>5,5$ (1906-2020)). B) Probability of Earthquake Occurrence in Chile.

(A)

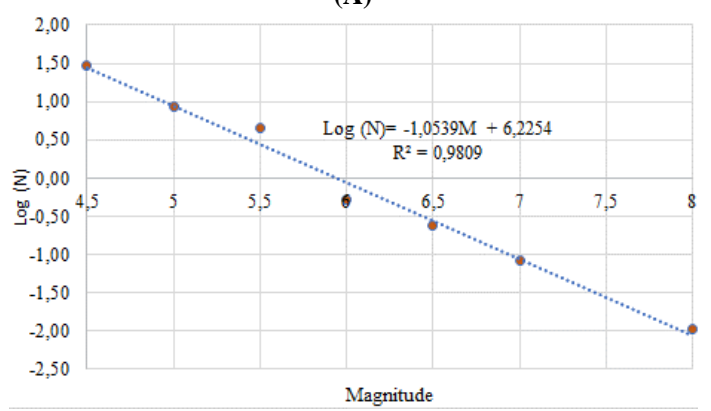

(B)

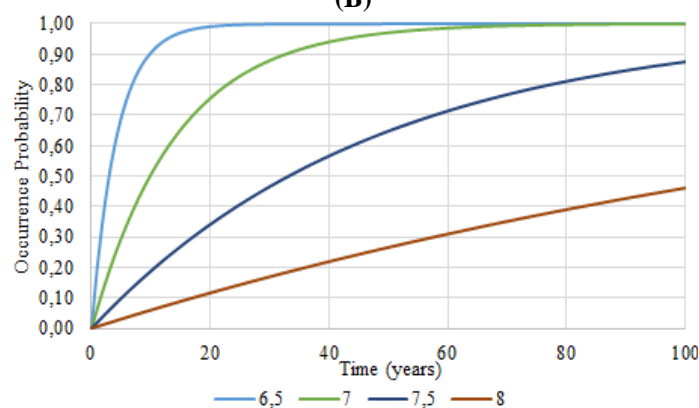

Fig. 5: A) Guttenberg-Richter Colombia $M>4,5$ ( $M \leq 5,5$ (2000-2020), $M>5,5$ (1924-2020)). B) Probability of Earthquake Occurrence in Colombia.

(A)

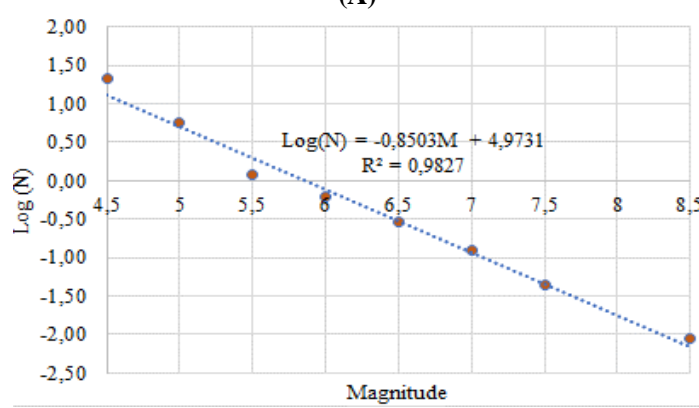

(B)

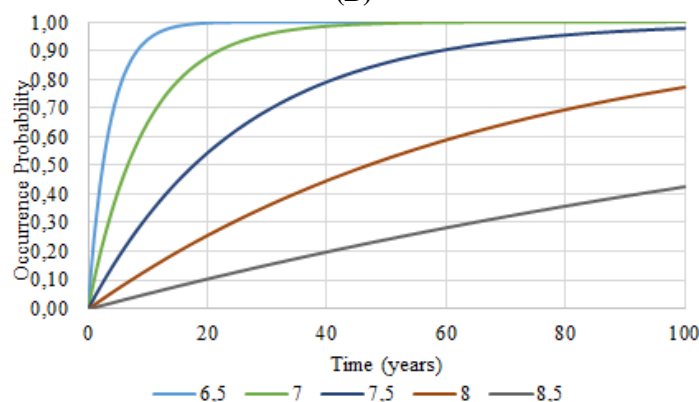

Fig. 6: A) Guttenberg-Richter Ecuador $M>4,5$ ( $M \leq 5,5$ (2000-2020), $M>5,5$ (1906-2020)). B) Probability of Earthquake Occurrence in Ecuador.

(A)

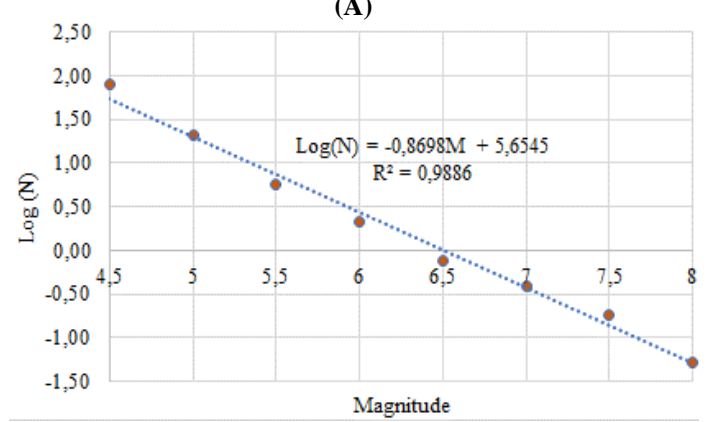

(B)

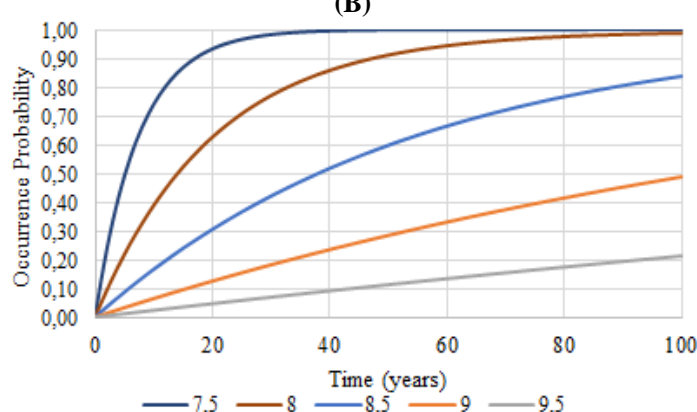

Fig. 7: A) Guttenberg-Richter Peru $M>4,5$ (M $\leq 6,5$ (2000-2020), $M>6,5$ (1906-2020)). B) Probability of Earthquake Occurrence in Peru

(A)

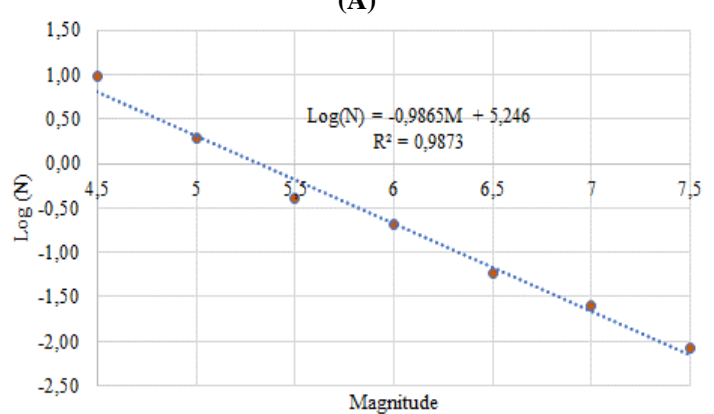

(B)

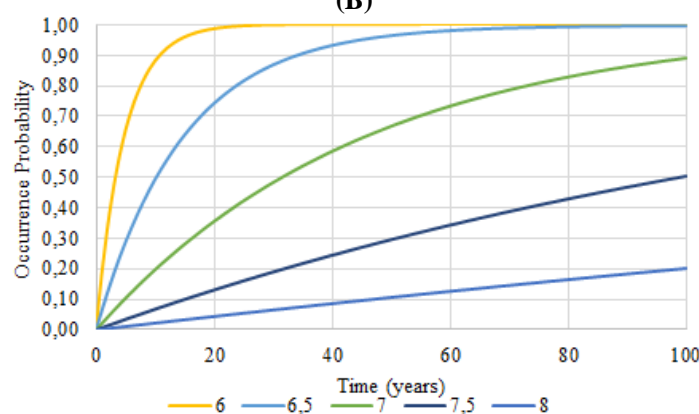

Fig. 8: A) Guttenberg-Richter Venezuela $M>4,5$ ( $M \leq 6,5$ (2000-2020), $M>6,5$ (1900-2020)). B) Probability of Earthquake Occurrence in Venezuela. 
The information was analyzed and computed for the entire Andean region, obtaining the probability of earthquake occurrence over magnitude 7 in 50 (Table 8) and 100 years (Table 9). The countries with the lowest probabilities are Venezuela and Bolivia, and the highest are Chile and Peru. In Figures 1b-8b, the curves of magnitudes which surpass a probability of occurrence greater than $20 \%$ in 100 years were included.

Table 8: Probability of Earthquake Occurrence in 50 Years

\begin{tabular}{|c|c|c|c|c|c|c|c|c|}
\hline Magnitude & Andean Region & Argentina & Bolivia & Chile & Colombia & Ecuador & Peru & Venezuela \\
\hline 7 & $100 \%$ & $100 \%$ & $94 \%$ & $100 \%$ & $97 \%$ & $99 \%$ & $100 \%$ & $67 \%$ \\
\hline 7,5 & $100 \%$ & $83 \%$ & $62 \%$ & $100 \%$ & $65 \%$ & $86 \%$ & $100 \%$ & $30 \%$ \\
\hline 8 & $100 \%$ & $40 \%$ & $29 \%$ & $99 \%$ & $27 \%$ & $52 \%$ & $92 \%$ & $11 \%$ \\
\hline 9 & $57 \%$ & $4 \%$ & $4 \%$ & $47 \%$ & $3 \%$ & $10 \%$ & $28 \%$ & $1 \%$ \\
\hline 9,5 & $26 \%$ & $1 \%$ & $1 \%$ & $21 \%$ & $1 \%$ & $4 \%$ & $12 \%$ & $0 \%$ \\
\hline
\end{tabular}

Table 9: Probability of Earthquake Occurrence in 100 Years

\begin{tabular}{|c|c|c|c|c|c|c|c|c|}
\hline Magnitude & Andean Region & Argentina & Bolivia & Chile & Colombia & Ecuador & Peru & Venezuela \\
\hline 7 & $100 \%$ & $100 \%$ & $100 \%$ & $100 \%$ & $100 \%$ & $100 \%$ & $100 \%$ & $89 \%$ \\
\hline 7,5 & $100 \%$ & $97 \%$ & $86 \%$ & $100 \%$ & $88 \%$ & $98 \%$ & $100 \%$ & $51 \%$ \\
\hline 8 & $100 \%$ & $64 \%$ & $49 \%$ & $100 \%$ & $46 \%$ & $77 \%$ & $99 \%$ & $20 \%$ \\
\hline 9 & $82 \%$ & $8 \%$ & $8 \%$ & $72 \%$ & $5 \%$ & $19 \%$ & $49 \%$ & $2 \%$ \\
\hline 9,5 & $45 \%$ & $3 \%$ & $3 \%$ & $38 \%$ & $2 \%$ & $7 \%$ & $22 \%$ & $1 \%$ \\
\hline
\end{tabular}

\section{Building codes}

Some of the countries of the Andean region have design and construction standards, which involve minimum seismic provisions according to the seismicity of the area, while others only design guides which still are not part of the laws of design and construction of the country, which implies that certain countries have a higher level of seismic risk than the others.

The first application of earthquake regulations in Andean countries goes back to 1935 in Chile [3]. Several countries have developed guidelines and regulations applicable to each country, with an update frequency between 12 and 20 years or with amending decrees which make slight changes to them. Bolivia is about to release its earthquake resistant construction regulations. In the case of Colombia, it is working on the NSR-20 regulations. The countries with recently updated standards in the last 5 years are Argentina and Peru. In Table 10 the actual and previous codes in the Andean countries are presented.

Table 10: Andean Countries and Their Previous and Actual Building Code (After Chavez [3])

\begin{tabular}{llll}
\hline Country & Current Code & Year & Previous Code \\
\hline Argentina & INPRES - CIRSOC.103[9] & 2018 & CIRSOC.103.2003, CISROC-103.1991, CIRSOC-1983, NAA 1980, CONCAR 1972 \\
Bolivia & GDBS [10]* & $2020^{*}$ & NBDS 2006 \\
Chile & NCh 433.Of1996 (Mod 2012) **[11] & 2009 & Nch2545.Of2003 (industrial facilities), Nch433.96, NCh433.Of93, Nch433.Of72 \\
Colombia & NSR-10[12] & 2010 & NSR-98, CCCSR 84 \\
Ecuador & NEC [13] & 2014 & INEN-5 2001 \\
Peru & E0.30 [14] & 2018 & E0.30 - 2003, 1997, 1977, 1970 \\
Venezuela & COVENIN 1756 [15] & 2001 & COVENIN 1756:98, COVENIN 1756:87, NP-MOP 1967 \\
\hline
\end{tabular}

*Regulated but still not implemented. ** "Third edition of "NCh 433".

\subsection{Seismic hazard, site classification and response spectra in building codes}

According to each guide or code used in Andean countries, there are several parameters in the construction of a response spectra, in this review the comparison parameters are: seismic hazard, site classification and response spectra.

i) Seismic hazard

Before the 2000 the majority of countries in Latin America in their building codes acknowledge seismic hazard as a subdivision of their country map in various seismic zones[3]. Peak ground acceleration (PGA) with a $10 \%$ exceedance probability in 50 years is commonly used factor to divide the maps in the Andean countries (Figure 9). In the case of Colombia, its code has three seismic hazard zones where PGA has values from 0 to 0.5 fraction of the gravity; the lower zone with PGA limit is $0.1 \mathrm{~g}$, the intermediate zone with $0.20 \mathrm{~g}$, and the upper zone with the highest value of $0.5 \mathrm{~g}$. The seismic hazard zone classification depends in the country seismicity, in the case of Chile, the lowest PGA used is 0.20 in zone 1 (which can be understood as a low zone), in comparison with the other countries this could be located in an intermediate zone. Bolivia and Argentina are the Andean countries with lowest limit PGA values to classify their seismic zones, since there is no exceedance above $0,35 \mathrm{~g}$ (Table 11 ).

Table 11: Andean Countries and Their Seismic Hazard Classification in PGA Values

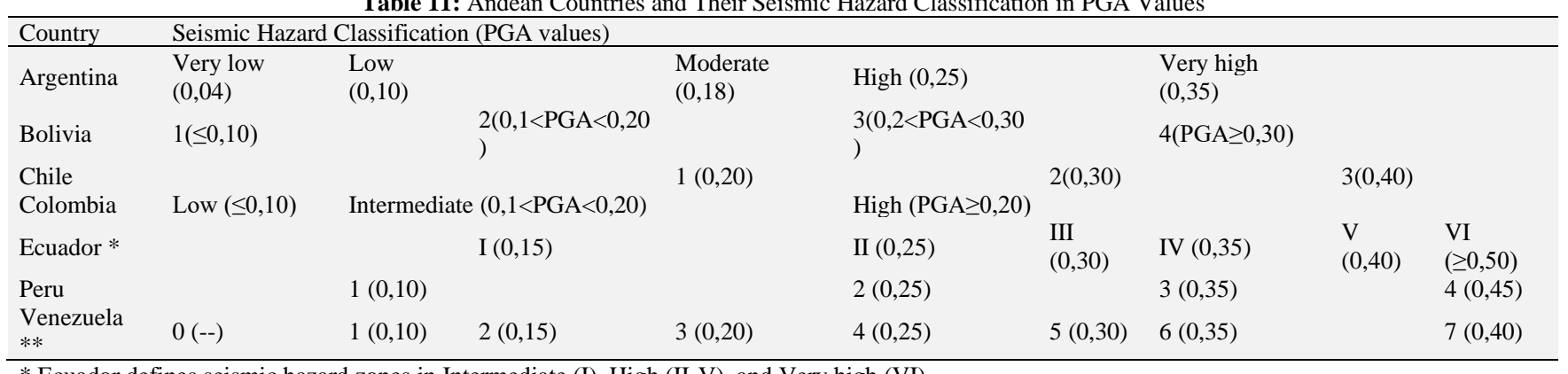

* Ecuador defines seismic hazard zones in Intermediate (I), High (II-V), and Very high (VI).

* Venezuela defines seismic hazard zones in Low (0-2), Intermediate (3-4), and High (5-7). 


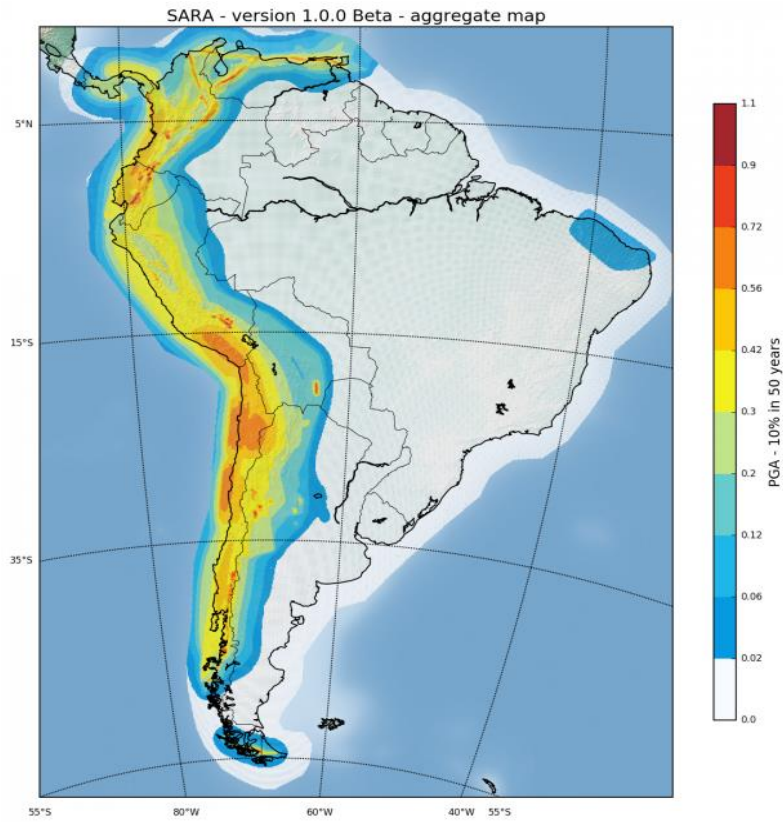

Fig. 9: South America Hazard Map (PGA 10\% in 50 Years - Return Period 475 Years) Source: South America Risk Assessment (SARA) Project. Retrieved from: Https://Sara.Openquake.Org/_Detail/Hazard:Rt7_Hazard_Map-Mean-0.002105-Pga_10293.Png?Id=Start.

ii) Site classification

The foundation soil and its properties affect the ground motion in the event of an earthquake and the variants that can be obtained from its classification determine the construction of the response spectra [6]. Each country presents the classifications of the site or soil typology according to several variables, the common variable being the speed of the average $S$ waves Vs in the first 30 meters of depth (Table 12, Figure 10), of the foundation ground. The countries have between 5 to 6 classes, with the soils with better behavior which have a wave velocity greater than $1500 \mathrm{~m} / \mathrm{s}$ and defining soft soils as those where additional geotechnical investigation is required. Other parameters used to classify soils are the number of blows N, from the SPT test, the resistance to unconfined compression qu, the resistance to unconfined shear Su and the plasticity index IP (Table 13). The country which uses more parameters is Peru, and the one which uses less is Venezuela.

Table 12: Andean Countries and Their Soil Classification in vs.

\begin{tabular}{|c|c|c|c|c|c|c|c|}
\hline Country & Soil Classific & ation (Vs) & & & & & \\
\hline Argentina & $\mathrm{SA}(\geq 1500)$ & SB $[760,1500)$ & $\mathrm{SC}[360,760)$ & $\mathrm{SD}[180,360)$ & & SE $[0,180)$ & SF (GIR) \\
\hline Bolivia & S0 $(\geq 1500)$ & $\mathrm{S} 1[760,1500)$ & $\mathrm{S} 2[370,760)$ & S3 $[180,370)$ & & $\mathrm{S} 4[0,180)$ & S5 (GIR) \\
\hline Chile & $\mathrm{A}(\geq 900)$ & $\mathrm{B}(\geq 500)$ & $C(\geq 350)$ & $\mathrm{D}(\geq 180)$ & & $\mathrm{E}[0,180)$ & $F(G I R)$ \\
\hline Colombia & $\mathrm{A}(\geq 1500)$ & В $[760,1500)$ & $\mathrm{C}[360,760)$ & $\mathrm{D}[180,360)$ & & $\mathrm{E}[0,180)$ & $F(G I R)$ \\
\hline Ecuador & $\mathrm{A}(\geq 1500)$ & $\mathrm{B}[760,1500)$ & $\mathrm{C}[360,760)$ & $\mathrm{D}[180,360)$ & & $\mathrm{E}[0,180)$ & $\mathrm{F}(\mathrm{GIR})$ \\
\hline Peru & So $(\geq 1500)$ & $\mathrm{S} 1[500,1500)$ & & $\mathrm{S} 2[180,500)$ & & $\mathrm{S} 3[0,180)$ & S4 (GIR) \\
\hline Venezuela & Hard Rock ( & $500)$ & $\begin{array}{l}\text { Soft Rock [ } 400, \\
500)\end{array}$ & $\begin{array}{l}\text { Very Dense Soil [250, } \\
400)\end{array}$ & $\begin{array}{l}\text { Dense Soil [170, } \\
250)\end{array}$ & $\begin{array}{l}\text { Stiff Soil }[0, \\
170)\end{array}$ & $\begin{array}{l}\text { Soft Soil } \\
\text { (GIR) }\end{array}$ \\
\hline
\end{tabular}

GIR: Geotechnical Investigation Required.

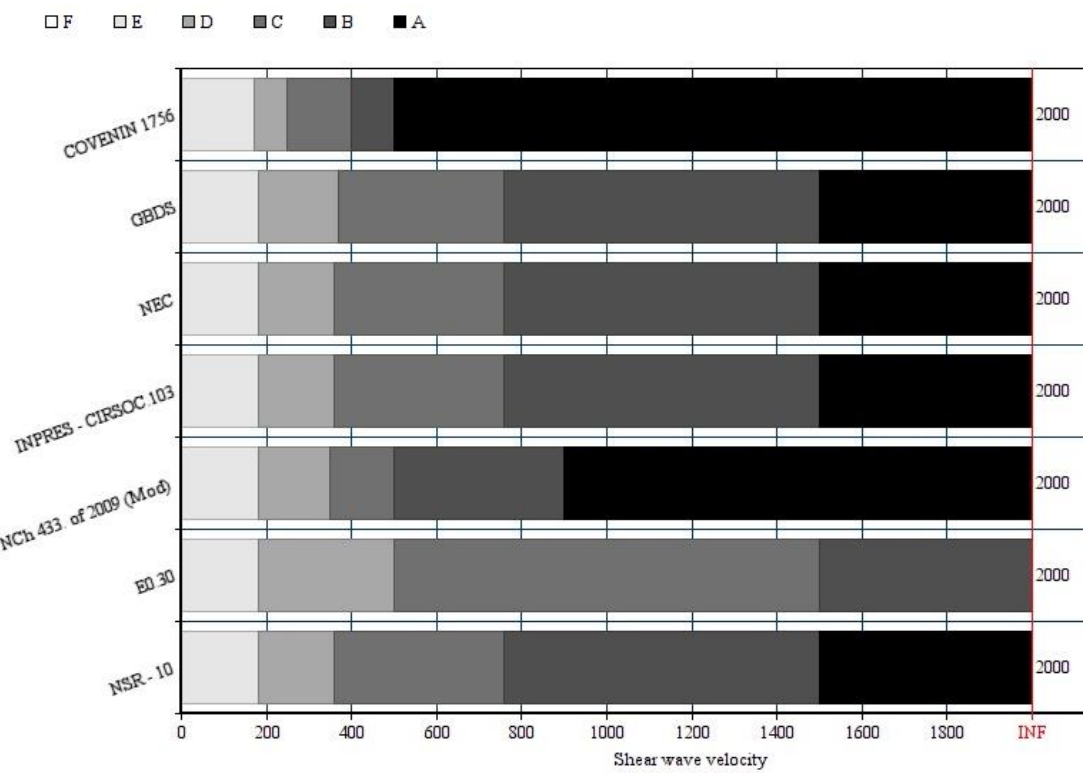

Fig. 9: Andean Countries and Their Soil Classification According to vs. 
Table 13: Soil Classification Parameters in Andean Countries Codes

\begin{tabular}{|c|c|c|c|c|c|c|c|}
\hline Soil-describing parameter & $\begin{array}{l}\text { Argentina } \\
\text { INPRES - CIR- } \\
\text { SOC. } 103\end{array}$ & $\begin{array}{l}\text { Bolivia } \\
\text { GBDS }\end{array}$ & $\begin{array}{l}\text { Chile } \\
\text { NCh 433.Of1996 (Mod } \\
\text { 2012) }\end{array}$ & $\begin{array}{l}\text { Colombia } \\
\text { NSR-10 }\end{array}$ & $\begin{array}{l}\text { Ecuador } \\
\text { NEC }\end{array}$ & $\begin{array}{l}\text { Peru } \\
\text { E0.30 }\end{array}$ & $\begin{array}{l}\text { Venezuela } \\
\text { COVENIN } \\
1756\end{array}$ \\
\hline $\begin{array}{l}\text { Avg. Shear wave velocity, Vs } \\
\text { SPT value, } \mathrm{N}_{60} \\
\text { Plasticity Index, IP } \\
\text { Unconfined compressive strength, qu } \\
\text { Unconfined shear strength, } \mathrm{Su}\end{array}$ & • & $\begin{array}{l}\bullet \\
\bullet \\
\bullet\end{array}$ & $\begin{array}{l} \\
\bullet \\
\bullet\end{array}$ & $\begin{array}{l}\bullet \\
\bullet \\
\bullet\end{array}$ & $\begin{array}{l}\bullet \\
\bullet \\
\bullet\end{array}$ & $\begin{array}{l} \\
\bullet \\
\bullet \\
\bullet \\
\bullet\end{array}$ & $\bullet$ \\
\hline
\end{tabular}

iii) Response Spectra

In the elastic response spectra for all the countries, the pseudo-accelerations are determined in function of the time and other parameters involved, with all spectra considering a structural damping of 5\%. The majority of functions have 3 to 4 zones (Figure 10), delimited by three periods T0, Ts and TL (these names are given as examples, the names vary in the countries standards), just in the case of NCh 433. Of1996 (Mod 2012), only a given period is used, the reason being that this function is the only one which does not have a plateu before the short period limit (T1). From the soil conditions, the periods T0, Ts and TL are defined. Some countries define few or many parameters to use in the spectrum depending on the type of soil and/or the coefficient of effective peak acceleration of the seismic zone (Table 14).

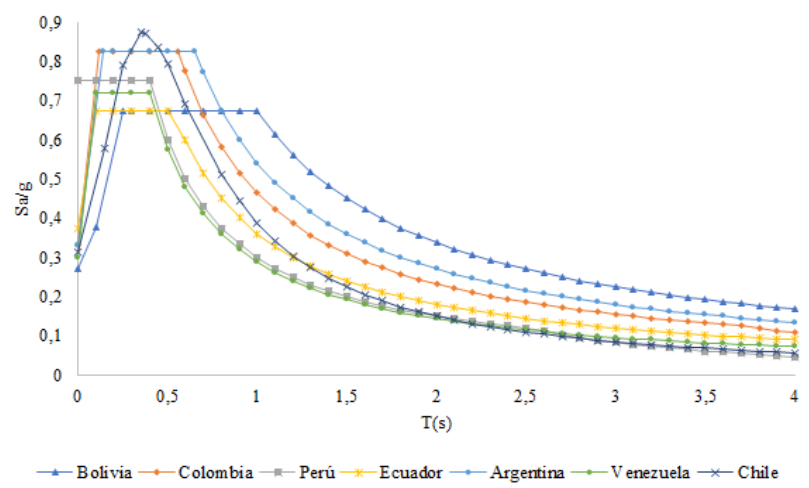

Fig. 10: Elastic Response Spectra for Each Country Standard, Constructed Taken into Account A PGA of 0,30g and A C Soil Type (NSR-10).

Table 14: Response Spectra Construction Parameters in Andean Countries Codes

\begin{tabular}{|c|c|c|c|c|c|c|c|}
\hline Response spectra parameter & $\begin{array}{l}\text { Argentina } \\
\text { INPRES - } \\
\text { CIRSOC.103 }\end{array}$ & Bolivia & $\begin{array}{l}\text { Chile } \\
\text { NCh } \\
\text { 433.Of1996 } \\
\text { (Mod 2012) } \\
\end{array}$ & $\begin{array}{l}\text { Colombia } \\
\text { NSR-10 }\end{array}$ & $\begin{array}{l}\text { Ecuador } \\
\text { NEC }\end{array}$ & $\begin{array}{l}\text { Peru } \\
\text { E0.30 }\end{array}$ & $\begin{array}{l}\text { Venezuela } \\
\text { COVENIN } \\
1756\end{array}$ \\
\hline $\begin{array}{l}\text { Vibration period where the zone of constant accelerations ends } \\
\text { for short periods, }\left(T_{2}, T s, T^{*}, T p\right)\end{array}$ & $\bullet$ & $\bullet$ & & $\bullet$ & $\bullet$ & $\bullet$ & $\bullet$ \\
\hline $\begin{array}{l}\text { Vibration period where the zone of approximately constant } \\
\text { displacements begins for long periods }\left(T_{3}, T_{1}\right)\end{array}$ & $\bullet$ & $\bullet$ & & $\bullet$ & & $\bullet$ & \\
\hline $\begin{array}{l}\text { Coefficients dependent on the type of soil and / or * and **, } \\
\text { which affect the value of the pseudo-acceleration spectrum in } \\
\text { different zones }(\mathrm{Fa}, \mathrm{Fs}, \mathrm{Fv}, \mathrm{S}, \mathrm{Ca}, \mathrm{Cv}, \beta, \mathrm{p}, \mathrm{r}, \varphi)\end{array}$ & $\bullet$ & $\bullet$ & $\bullet$ & $\bullet$ & $\bullet$ & $\bullet$ & $\bullet$ \\
\hline Coefficient of effective peak acceleration* (Aa, So, Z, Ao) & & $\bullet$ & $\bullet$ & $\bullet$ & $\bullet$ & $\bullet$ & $\bullet$ \\
\hline Coefficient of effective peak velocity** (Av) & & & & $\bullet$ & & & \\
\hline Occupancy factor $\left(\mathrm{I}, \alpha, \gamma_{\mathrm{r}, \mathrm{U}}\right)$ & & & & $\bullet$ & & $\bullet$ & $\bullet$ \\
\hline
\end{tabular}

\section{Static seismic analysis}

In order to verify similarities or discrepancies between codes, a static seismic analysis has been carried out for a building in reinforced concrete (Table 15, Figure 11), in an intermediate-to-high zone (in some countries an intermediate zone is a high zone in another) according to a PGA of $0.30 \mathrm{~g}$ and a C soil classification acroding to NSR-10[12] (For the other countries, the correspondent soil classification was determined).

Table 15: Summary of the Parameters Considered in the Static Analysis

\begin{tabular}{ll}
\hline Parameter & Description \\
\hline Type of structure & Special moment resistance frame RC \\
Seismic zone & According to each country, for this example is used a PGA of $0,30 \mathrm{~g}$ \\
Number of stories & 4 \\
Floor height & $3,2 \mathrm{~m}$ \\
Distance between columns & $4 \mathrm{~m}$ \\
Dimension in X & $16 \mathrm{~m}$ \\
Dimension in Y & $12 \mathrm{~m}$ \\
Imposed Load & $3,86 \mathrm{kN} / \mathrm{m}^{2}$ \\
Material & Reinforced concrete $\mathrm{f}^{\prime} \mathrm{c}=28 \mathrm{Mpa}$ \\
Beam section & $0,30 \mathrm{x} 0,40 \mathrm{~m}$
\end{tabular}




\begin{tabular}{ll} 
Joist section & $0,15 \times 0,40 \mathrm{~m}$ \\
Column section & $0,40 \mathrm{x} 0,40 \mathrm{~m}$ \\
Slab thickness & $0,08 \mathrm{~m}$ \\
Specific weight of RC & $24 \mathrm{kN} / \mathrm{m}^{3}$ \\
Type of soil & Soft-Hard Rock \\
Occupancy & Residential \\
\hline
\end{tabular}

(A)

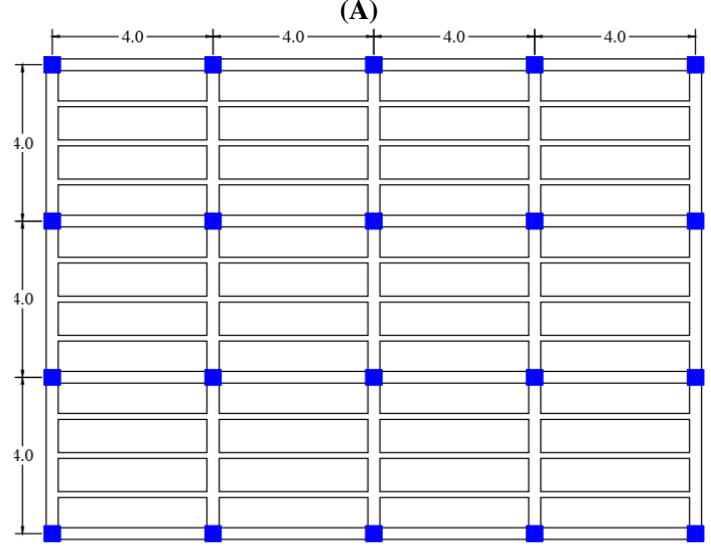

Fig. 11: A) Plan View of the Building for the Static Analysis; B) Elevation View of the Building for the Static Analysis.
(B)

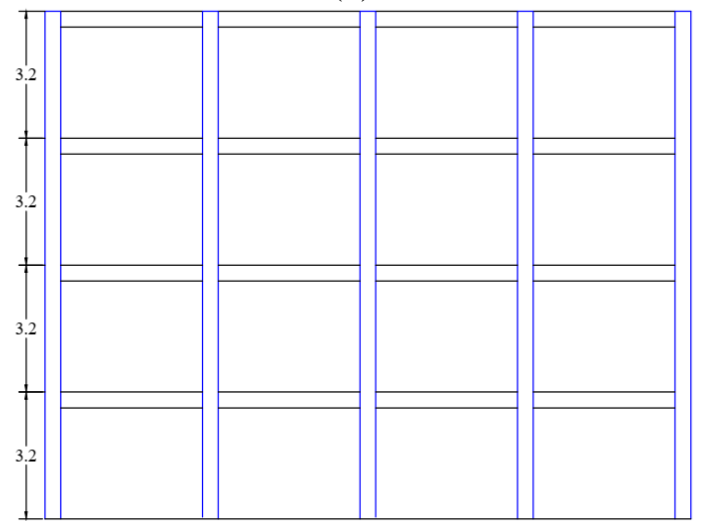

In Tables 17 to 23 we find the results of the lateral design load calculated at each floor for all the countries. These numbers show that the results for the design shear are similar for some countries such as Colombia, Chile and Bolivia. In the case of Ecuador and Peru, which has a response modification factor of 8 (Table 16), the shears are lower; the standard that handles the lowest shear is the Venezuelan and the one with the highest shear is Argentina for the building under study (Figure 12). Also, the shears are presented without being affected by the response modification factor, where the uniformity between codes of Argentina, Chile, Colombia and Peru can be better appreciated. (Figure 13).

Table 16: Response Modification Factor for Special Moment Resistant Frame RC in Andean Countries Codes

\begin{tabular}{|c|c|c|c|c|c|c|c|}
\hline & $\begin{array}{l}\text { Argentina } \\
\text { INPRES - CIR- } \\
\text { SOC. } 103\end{array}$ & $\begin{array}{l}\text { Bolivia } \\
\text { GBDS }\end{array}$ & $\begin{array}{l}\text { Chile } \\
\text { NCh 433.Of1996 } \\
(\text { Mod 2012) }\end{array}$ & $\begin{array}{l}\text { Colombia } \\
\text { NSR-10 }\end{array}$ & $\begin{array}{l}\text { Ecuador } \\
\text { NEC }\end{array}$ & $\begin{array}{l}\text { Peru } \\
\text { E0.30 }\end{array}$ & $\begin{array}{l}\text { Venezuela } \\
\text { COVENIN } \\
1756 \\
\end{array}$ \\
\hline $\begin{array}{l}\text { Response modification factor used in the static seismic } \\
\text { analysis (Special moment resistance frame RC) }\end{array}$ & 7 & 7 & 7 & 7 & 8 & 8 & 6 \\
\hline
\end{tabular}

Table 17: Design Lateral Loads at Each Story Estimated Per INPRES - CIRSOC.103 (Argentina) for the Building

\begin{tabular}{llll}
\hline Story Level & $\mathrm{w}^{* h}$ & $\mathrm{w} * \mathrm{~h} / \Sigma(\mathrm{w} * \mathrm{~h})$ & $\mathrm{F}(\mathrm{KN})$ \\
\hline 1 & 5587,35 & 0,10 & 81,79 \\
2 & 11174,71 & 0,20 & 163,59 \\
3 & 16762,06 & 0,30 & 245,38 \\
4 & 22349,41 & 0,40 & 327,18 \\
$\Sigma$ & 55873,54 & 1,00 & 817,94 \\
\hline
\end{tabular}

Table 18: Design Lateral Loads at Each Story Estimated Per GBDS (Boliva) for the Building

\begin{tabular}{|c|c|c|c|}
\hline Story Level & $\mathrm{w}^{*} \mathrm{~h}^{\wedge} \mathrm{k}$ & $\mathrm{w}^{*} \mathrm{~h}^{\wedge} \mathrm{k} / \Sigma\left(\mathrm{w}^{*} \mathrm{~h}^{\wedge} \mathrm{k}\right)$ & $\mathrm{F}(\mathrm{KN})$ \\
\hline 1 & 6086,56 & 0,09 & 66,73 \\
\hline 2 & 12810,01 & 0,20 & 140,44 \\
\hline 3 & 19796,87 & 0,30 & 217,03 \\
\hline$\Sigma$ & 65653,91 & 1,00 & 719,76 \\
\hline
\end{tabular}

Table 19: Design Lateral Loads at Each Story Estimated Per Nch 433.of 1996 (Mod 2012) (Chile) for the Building

\begin{tabular}{llll} 
& \multicolumn{2}{c}{ Table 19: Design Lateral Loads at Each Story Estimated Per Nch 433.of 1996 (Mod 2012) (Chile) for the Building } \\
\hline Story Level & Ak & Ak Pk & Ak Pk/ $(\mathrm{Ak}$ Pk) \\
\hline 1 & 0,13 & 233,93 & 0,13 \\
2 & 0,16 & 277,48 & 0,16 \\
3 & 0,21 & 361,62 & 0,21 \\
4 & 0,50 & 873,02 & 0,50 \\
$\Sigma$ & 1,00 & 1746,05 & 1,00 \\
\hline
\end{tabular}

Table 20: Design Lateral Loads at Each Story Estimated Per NSR-10 (Colombia) for the Building

\begin{tabular}{llll}
\hline Story Level & $\mathrm{w}^{*} \mathrm{~h}^{\wedge} \mathrm{k}$ & $\mathrm{CV}$ & $\mathrm{F}(\mathrm{KN})$ \\
\hline 1 & 5918,79 & 0,10 & \\
2 & 12251,16 & 0,20 & \\
3 & 18749,63 & 0,30 & 152,34 \\
4 & 25358,37 & 0,41 & 233,15 \\
$\Sigma$ & 62277,94 & 1,00 & 315,33 \\
\hline
\end{tabular}

Table 21: Design Lateral Loads at Each Story Estimated Per NEC (Ecuador) for the Building

\begin{tabular}{llll}
\hline Story Level & $\mathrm{w}^{*} \mathrm{~h}^{\wedge} \mathrm{k}$ & $\mathrm{Cv}$ & \\
\hline 1 & 5737,42 & 0,10 & $\mathrm{~F}(\mathrm{KN})$ \\
2 & 11657,50 & 0,20 & 114,51 \\
3 & 17648,56 & 0,30 & 173,35
\end{tabular}




\begin{tabular}{|c|c|c|c|}
\hline $\begin{array}{l}4 \\
\Sigma\end{array}$ & $\begin{array}{l}23686,16 \\
58729,64\end{array}$ & $\begin{array}{l}0,40 \\
1,00 \\
\end{array}$ & $\begin{array}{l}232,66 \\
576,87 \\
\end{array}$ \\
\hline & & & \\
\hline Story Level & $\mathrm{Pi}^{*} \mathrm{hi}^{\wedge} \mathrm{k}$ & $\alpha$ & $\mathrm{F}(\mathrm{KN})$ \\
\hline 1 & 5587,35 & 0,10 & 69,98 \\
\hline 2 & 11174,71 & 0,20 & 139,95 \\
\hline 3 & 16762,06 & 0,30 & 209,93 \\
\hline 4 & 22349,41 & 0,40 & 279,91 \\
\hline$\Sigma$ & 55873,54 & 1,00 & 699,77 \\
\hline
\end{tabular}

\begin{tabular}{lllll}
\multicolumn{2}{c}{ Table 23: Design Lateral Loads at Each Story Estimated Per COVENIN 1756 (Venezuela) for the Building } \\
\cline { 1 - 3 } Story Level & $\mathrm{w}^{*} \mathrm{~h}$ & $\mathrm{w}^{*} \mathrm{~h} / \Sigma\left(\mathrm{w}^{*} \mathrm{~h}\right)$ & $\mathrm{Ft}(\mathrm{KN})$ & $\mathrm{Fi}(\mathrm{KN})$ \\
\hline 1 & 5587,35 & 0,10 & 0,00 & 42,34 \\
2 & 11174,71 & 0,20 & 0,00 & 84,69 \\
3 & 16762,06 & 0,30 & 0,00 & 127,03 \\
4 & 22349,41 & 0,40 & 36,56 & 169,38 \\
$\Sigma$ & 55873,54 & 1,00 & - & 42,34 \\
\hline
\end{tabular}

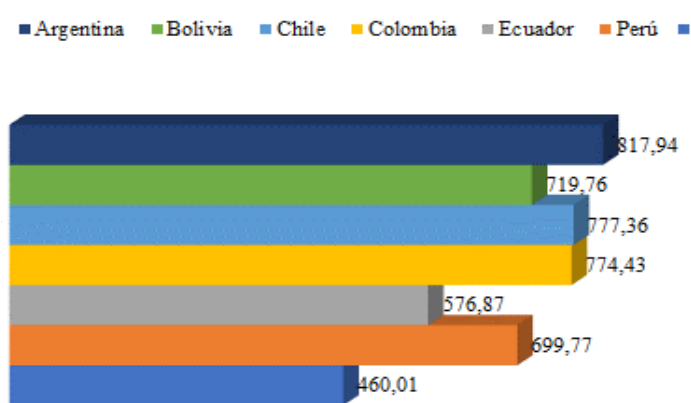

Fig. 12: Andean Countries and Their Seismic Base Shear in KN (Affected by R: Response Modification Factor) for the Building (Table 15, Figure11).

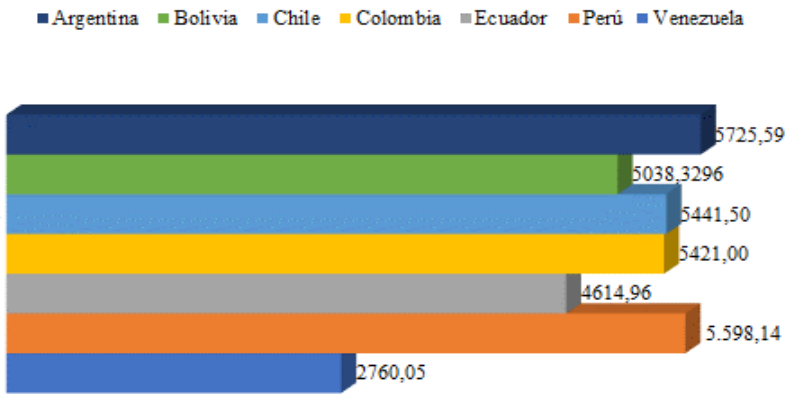

Fig. 13: Andean Countries and Their Base Shear in KN (Not Affected by R: Response Modification Factor) for the Building (Table 15, Figure11).

\section{Conclusion}

Seismic provisions for the Andean countries have been presented, and in the case of seismic hazard the distribution is not uniform since all the countries have different seismic records, as shown previously in the historic seismicity section. Some countries use a set value for certain zones and others use a range of values (as is the case of Bolivia and Colombia). The country with the lowest inferior limit is Venezuela, and Chile with the highest; while those that consider a lower superior limit are Argentina and Bolivia, with Ecuador having the highest superior limit.

In the site classification section, only Peru presents five types of soil, while the others consider a total of six. In the case of Venezuela, the ranges differ from others and it is the only country that uses a single parameter to classify the types (Venezuela also has the oldest code among the countries), while the other countries have at least three, with Peru being the country with the most parameters at five.

While going through the pseudo-acceleration spectra, we find Bolivia as the country with the widest plateau, Argentina and Colombia with the highest, Chile with no plateau; and along with Ecuador, Peru and Bolivia, these countries have the deepest plunge when we leave the short period zone. The spectrum with the best ease of construction is the Chilean one, while the most complex is the Venezuelan one.

The most notable difference is observed when calculating the seismic forces for the code of each country. The average design seismic shear is $684 \mathrm{KN}$ with a standard deviation of $139 \mathrm{KN}(20 \%)$. Countries like Bolivia and Peru are the closest to this average value. The shear force not affected by the response modification factor is $4924 \mathrm{KN}$, with a standard deviation of $1033 \mathrm{KN}$ (21\%); countries like Colombia, Chile, Bolivia and Ecuador are the closest to this average. The code with the smallest shear in both cases is the Venezuelan code, and the highest in both cases is the Argentinian code.

In general, there are many similarities in soil classification. Discrepancies are mayorly present in the way the made spectra calculations, the response modification factor values that each code considers according to the structural system, and some additional parameters in determining the design seismic force. For future research, dynamic analysis of seismic forces and execution of a structural design with specialized software is recommended. 


\section{Acknowledgement}

Special thanks to The Kizuna Project, "Human Resources Training Program for Latin America and the Caribbean in Disaster Risk Reduction", to the cooperation agencies that coordinate it, JICA and AGCID, and my classmates who provided me with the current codes used in their countries.

\section{References}

[1] Naciones Unidas, La Agenda 2030 y los Objetivos de Desarrollo Sostenible: una oportunidad para América Latina y el Caribe (LC/G.2681 P/Rev.3). Santiago, 2018.

[2] United Nations, "Sendai Framework for Disaster Risk Reduction 2015 - 2030." UNISDR/GE/2015 - ICLUX EN5000 1st edition, 2015.

[3] J. Chavez, O. Khemici, M. Khater, and P. Keshishian, "Building Codes and Relative Seismic Vulnerability in Latin American Countries," p. 10.

[4] P. Giri, A. D. Bhatt, D. Gautam, and H. Chaulagain, "Comparison between the seismic codes of Nepal, India, Japan, and EU," Asian J Civ Eng, vol 20, no. 2, pp. 301-312, Feb. 2019, https://doi.org/10.1007/s42107-018-0102-8.

[5] S. Santos, C. Giardelis, M. trykova, C. Bucur, L. Zanaica, and S. Lima, "Comparative Study of a Set of Codes for the Seismic Design of Buildings," vol. 1, p. 136, Sep. 2017.

[6] V. Khose, Y. Singh, and D. Lang, "A Comparative Study of Design Base Shear for RC Buildings in Selected Seismic Design Codes,” Earthquake Spectra, vol. 28, pp. 1047-1070, Aug. 2012, https://doi.org/10.1193/1.4000057.

[7] B. K. Horton, "Tectonic Regimes of the Central and Southern Andes: Responses to Variations in Plate Coupling During Subduction," Tectonics, vol. 37, no. 2, pp. 402-429, 2018, https://doi.org/10.1002/2017TC004624.

[8] C. Dimaté et al., "Seismic hazard assessment in the Northern Andes (PILOTO Project)," Annali di Geofisica, vol. 42, no. 6, 1999, Accessed: Feb. 24, 2020. [Online]. Available: https://www.annalsofgeophysics.eu/index.php/annals/article/view/3787.

[9] Ministerio del Interior, Obras Públicas y Vivienda and Instituto Nacional de Prevención Sísmica, Reglamento Argentino para Construcciones Sismorresistentes INPRES-CIRSOC 103. Argentina: INTI, 2018

[10] Ministerio de Obras Públicas, Servicios y Vivienda, Guía Boliviana de Diseño Sísmico. Bolivia, 2020.

[11] Instituto Nacional de Normalización, NCh433.Of1996 Modificada en 2012, Diseño Sísmico de Edificios. Chile, 2012.

[12] Ministerio de Ambiente, Vivienda y Desarrollo Territorial, NSR-10, Reglamento Colombiano de Construcción Sismo Resistente. Colombia, 2010.

[13] Ministerio de Desarrollo Urbano y Vivienda and Cámara de la Industria de Construcción, NEC, Norma Ecuatoriana de la Construcción. Ecuador, 2014.

[14] Ministerio de Vivienda, Construcción y Saneamiento, Norma Técnica E.30 “Diseño Sismorresistente.” Perú, 2018.

[15] Fundación Venezolana de Investigaciones Sismológicas, Edificaciones Sismo Resistentes, Parte I: Requisitos (COVENIN 1756), Ministerio de Ciencia y Tecnología. Venezuela, 2001. 